Article

\title{
Shifts of the Mean Centers of Potential Vegetation Ecosystems under Future Climate Change in Eurasia
}

\author{
Zemeng Fan 1,2,3,* and Bin Fan 1,2 \\ 1 State Key Laboratory of Resources and Environmental Information System, Institute of Geographic Sciences \\ and Natural Resources Research, Chinese Academy of Sciences, Beijing 100101, China; fanb@lreis.ac.cn \\ 2 College of Resources and Environment, University of Chinese Academy of Sciences, Beijing 100049, China \\ 3 Jiangsu Center for Collaborative Innovation in Geographical Information Resource Development and \\ Application, Nanjing 210023, China \\ * Correspondence: fanzm@lreis.ac.cn; Tel.: +86-10-6488-8957
}

Received: 2 August 2019; Accepted: 2 October 2019; Published: 4 October 2019

check for updates

\begin{abstract}
Climate change dominantly controls the spatial distributions of potential vegetation ecosystems; the shift trends in the mean centers of potential vegetation ecosystems could be used to explain their responses to climate change. In terms of the climate observation data of Eurasia for the period from 1981 to 2010 and the climate scenario data for the period from 2011 to 2100 under the three Representative Concentration Pathways (RCPs) scenarios of RCP2.6, RCP4.5 and, RCP8.5, which were released by the Coupled Model Intercomparison Project Phase 5 (CMIP5), the Holdridge Life Zone (HLZ) ecosystem model was improved to quantitatively classify the potential vegetation types, and the shift model of mean center was adopted to compute the trends in the spatiotemporal shifts of potential vegetation types in Eurasia. The results showed that the mean centers of the major potential vegetation ecosystems would be distributed in the central and southern parts of Eurasia. Under the RCP2.6, RCP4.5, and RCP8.5 scenarios, the potential shift distances of the mean centers of the vegetation types under the RCP8.5 scenario would be the largest, and those of the polar/nival area, subpolar/alpine moist tundra, warm temperate dry forest, subtropical moist forest, cool temperate moist forest, cool temperate wet forest, subtropical wet forest, subtropical thorn woodland, warm temperate moist forest and subtropical dry forest would be larger than those in the other potential vegetation types in Eurasia. Moreover, the shift directions of the mean centers of the major potential vegetation types would generally shift northward, and subtropical dry forest, warm temperate moist forest and subpolar/alpine moist tundra would be the most sensitive to change among all vegetation types under the three scenarios for the period from 2011 to 2100.
\end{abstract}

Keywords: potential vegetation ecosystem; mean center; shift scenarios; climate change; Eurasia

\section{Introduction}

Changes in vegetation ecosystems, which are major indicators of global change on the Earth's surface, play a crucial role in maintaining the human living environment and its sustainable development [1,2]. Climate change, as an important aspect of global change, has caused a series of changes in the spatiotemporal distribution of vegetation ecosystems [3-5]. The interactions between climate and vegetation ecosystems have always been a hot topic in global change research [6]. A long-term investigation of the correlation between climate change and vegetation ecosystem change [7] showed that there was a strong correlation between climate change and vegetation distributions [8], and that the climate exerts the dominant control on the distributions of the major vegetation types on a large scale [9]. The key climate parameters of biotemperature, precipitation and evaporation directly determine the changes in the spatial distribution of terrestrial ecosystems [10-15]. A series of 
models have been developed to simulate the spatial distributions of vegetation ecosystems [16], in which the dominant models include the Holdridge Life Zone ( HLZ) ecosystem model [9], the model of predicting physiognomic vegetation types with climate variables developed by Box E.O.(BOX) [17], Dynamic Global Phytogeography Model (DOLY) [8], Mapped Atmosphere-Plant Soil System (MAPSS) model [18] and Integrated BIosphere Simulator (IBIS) [19]. In particular, the HLZ ecosystem model has been widely used and is considered an effective method for simulating the potential distributions of vegetation ecosystems [20-24] because the model parameters only involve the three key climatic factors: Mean annual biotemperature (MAB), average total annual precipitation (TAP) and potential evapotranspiration ratio (PER) [25-27].

Since the early 2000s, a continuous effort has been made to understand the relationship between vegetation distributions and climate change [28-30], especially to reveal the response of vegetation to climate change [31,32]. For instance, an analysis of the historical vegetation and climate data showed that the forest distribution had shifted to the polar region [33]; grass distribution was more sensitive to change than any other vegetation ecosystems in Central Asia [34]; the mean centers of the different terrestrial ecosystems in China showed different shift trends from 1960 to 2002 [35]; the mean center shift of vegetation ecosystem would influence the ecosystem service value [36]; and the mean centers of vegetation ecosystems would show a different shift trend under different climate change scenarios [37]. However, current research mainly focuses on the responses of the shift in the mean center of vegetation ecosystems to historical climate change [38], and is rarely involved in analyzing the response relations between the different shift trends of vegetation ecosystems and climate change in the future.

To explicitly analyze the responses of the different shift trends in vegetation ecosystem types to the different climate change scenarios in Eurasia, the Holdridge Life Zone (HLZ) ecosystem model has been improved to quantitatively classify the potential vegetation types, and the shift model of mean center has been adopted to compute the spatiotemporal shift trends of potential vegetation types. The shift trends of the mean centers in different potential vegetation ecosystems from 2010 to 2100 were obtained from the climate observation data from 1981 to 2100 in Eurasia and the climate scenarios data released by CMIP5 from 2011 to 2100 . The different shift distances and directions of the mean center in the different vegetation ecosystem types were compared under the three scenarios of RCP2.6, RCP4.5, and RCP8.5, and we discuss which vegetation ecosystem types will be more sensitive to climate change in Eurasia in the future.

\section{Materials and Methods}

\subsection{Data Sources}

The basic climate datasets include the observation data and the scenario data. The observational monthly climate data from 1981 to 2010 were collected from 1360 weather stations in Eurasia as seen in Figure 1. The climate scenario data for the CMIP5 RCP2.6, RCP4.5, and RCP8.5 scenarios from 2011 to 2100 were obtained from the IPCC website. The three climate scenarios of RCP2.6, RCP4.5 and RCP8.5 represent scenarios of low, middle and high emissions of greenhouse gases, respectively (http://www.ipcc-data.org) [39]. The Digital Elevation Model (DEM) data seen in Figure 1 was derived from the Shuttle Radar Topography Mission (SRTM) data (http://srtm.csi.cgiar.org) with a spatial resolution of $1 \mathrm{~km} \times 1 \mathrm{~km}$ resampled to a resolution of $0.125^{\circ} \times 0.125^{\circ}$. 


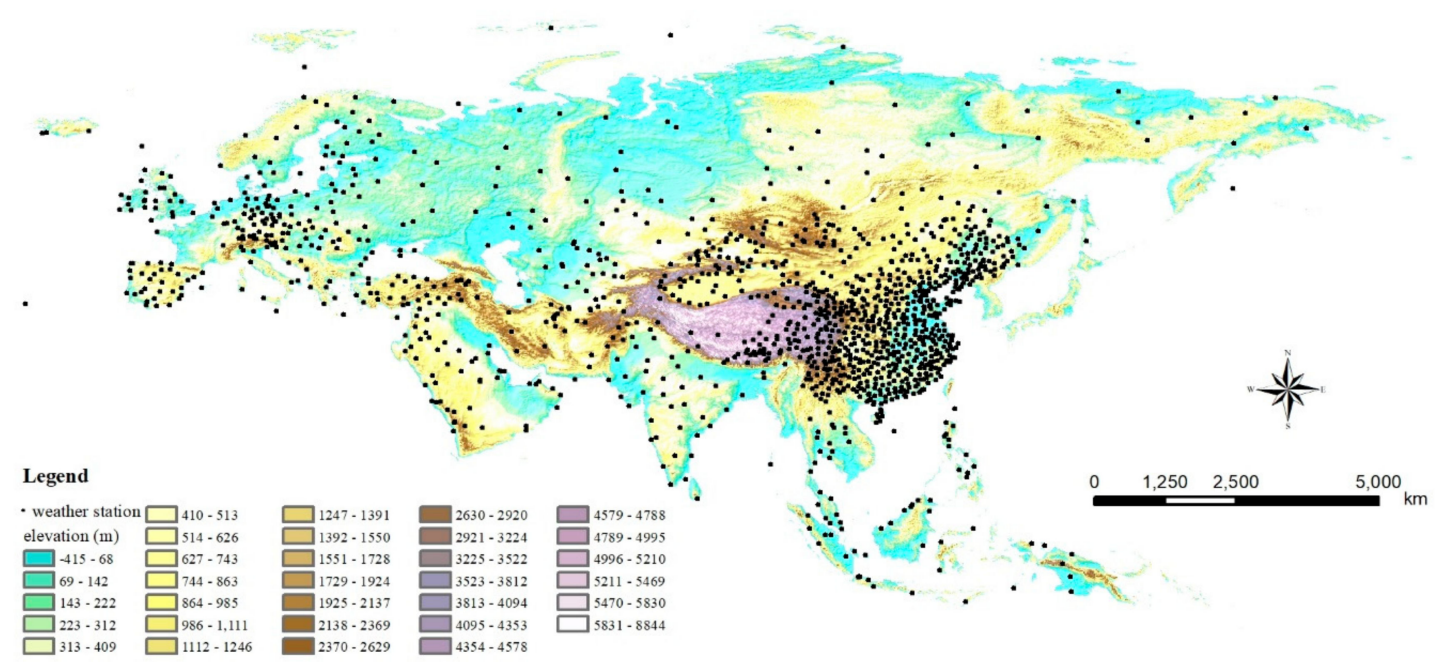

Figure 1. Digital Elevation Model (DEM) data and 1360 weather stations in Eurasia.

The accuracy of spatial distribution data of the climate variables obtained from the observational scatter data and low resolution scenario data is important to the HLZ ecosystem model and the shift model of mean center, which directly affects the quality of the results of the simulation of the shift trends of the mean centers of potential vegetation ecosystems under climate change [11].

The main interpolation and downscaling methods included the inverse distance weighted (IDW) model, kriging (Kriging) model, spline interpolation (Spline) model, triangulated irregular network (TIN) model and high accuracy surface modeling (HASM) method. The IDW model uses an inverse distance weighting function to determine the interpolation value while ignoring the information beyond the neighborhood. Although the Kriging model attempts to have an error equal to zero, this goal is nearly unattainable. The Spline model applies univariate cubic basis-splines to simulate surfaces, but few types of surfaces fit the splines. The TIN model uses a linear function to calculate the value of each point but ignores nonlinear information. HASM is a new method based on the differential geometry theory that could overcome the drawbacks of the IDW, Kriging, Spline and TIN methods [40], and the accuracy of the interpolated and downscaled climate data could be generally increased by $5 \%$ compared with that of the other three methods $[41,42]$. Thus, the HASM method was selected to obtain the spatial grid data of MAB, TAP and PER with a spatial resolution of $0.125^{\circ} \times 0.125^{\circ}$ by combining the longitude, latitude and elevation data during the periods from 1981 to 2010 (T0), 2011 to 2040 (T1), 2041 to 2070 (T2) and 2071 to 2100 (T3); the specific methods are described in the references [40-42].

\subsection{Methods}

\subsubsection{The HLZ Ecosystem Classification}

The HLZ ecosystem model is a classification system for different HLZ ecosystem types in terms of the three bioclimatic factors: Mean annual biotemperature (MAB), average total annual precipitation (TAP) and potential evapotranspiration ratio (PER) [9,11,23,37]. The HLZ ecosystem model was improved to simulate the potential vegetation ecosystems throughout Eurasia and can be expressed as

$$
\begin{gathered}
\operatorname{MAB}(x, y, t)=\frac{1}{365} \sum_{j=1}^{365} \operatorname{TEM}(j, x, y, t) \\
\operatorname{TAP}(x, y, t)=\sum_{j=1}^{365} P(j, x, y, t) \\
\operatorname{PER}(x, y, t)=\frac{58.93 M A B(x, y, t)}{\operatorname{TAP}(x, y, t)}
\end{gathered}
$$




$$
H L Z_{i}(x, y, t)=\sqrt{\left(M(x, y, t)-M_{i 0}\right)^{2}+\left(T(x, y, t)-T_{i 0}\right)^{2}+\left(P(x, y, t)-P_{i 0}\right)^{2}}
$$

where $\operatorname{MAB}(x, y, t), \operatorname{TAP}(x, y, t)$ and $\operatorname{PER}(x, y, t)$ are the MAB $\left({ }^{\circ} \mathrm{C}\right), \mathrm{TAP}(\mathrm{mm})$ and PER, respectively, at grid $(x, y)$ in period $\mathrm{t} ; \operatorname{TEM}(j, x, y, t)$ and $P(j, x, y, t)$ are respectively the accumulated temperature above $0{ }^{\circ} \mathrm{C}$ and below $30^{\circ} \mathrm{C}$ and the total precipitation on the $j$ th day; $M_{i 0}, T_{i 0}$ and $P_{i 0}$ are respectively the values of the MAB logarithm, TAP logarithm and PER logarithm at the central point of the ith potential vegetation type in the HLZ ecosystem criterion; $M(x, y, t)=\ln M A B(x, y, t), T(x, y, t)=\ln T A P(x, y, t)$, and $P(x, y, t)=\ln P E R(x, y, t)$; and $H L Z_{i}(x, y, t)$ is the $i$ th potential vegetation type.

\subsubsection{Shift Model of Mean Center in Potential Vegetation Ecosystems}

The original mean center model was developed to calculate the mean centers of the population distributions in the USA population census in 1870 [43] and has been mainly used in economic geography [44-46]. Since the 2000s, the mean center model has been improved gradually to compute the shift trends of the mean centers of terrestrial ecosystems [11,35,37] and land cover types [47]. In this study, the mean center model was improved to compute the spatial distribution of the mean centers of different potential vegetation ecosystem types in Eurasia during the periods from T0 to T3, which can be formulated as

$$
\begin{aligned}
& x_{j}(t)=\sum_{i=1}^{I_{j}(t)} \frac{s_{i j}(t) \cdot X_{i j}(t)}{S_{j}(t)} \\
& y_{j}(t)=\sum_{i=1}^{I_{j}(t)} \frac{S_{i j}(t) \cdot Y_{i j}(t)}{S_{j}(t)}
\end{aligned}
$$

where $t$ represents time; $I_{j}(t)$ is the number of patches of the $j$ th potential vegetation type; $s_{i j}(t)$ is the area of the $i$ th patch in the $j$ th potential vegetation type; $S_{j}(t)$ is the total area of the $j$ th potential vegetation type; $\left(X_{i j}(t), Y_{i j}(t)\right)$ are the longitude and latitude coordinates of the geometric center of the $i$ th patch in the $j$ th potential vegetation type; and $\left(x_{j}(t), y_{j}(t)\right)$ is the mean center coordinate of the $j$ th potential vegetation type.

To simulate the shift distance and direction of the mean center of different potential vegetation types, a shift trend model of mean center has been developed by extending the mean center model [11,48], which can be expressed as

$$
\begin{gathered}
d_{j}=\sqrt{\left(x_{j}(t+1)-x_{j}(t)\right)^{2}+\left(y_{j}(t+1)-y_{j}(t)\right)^{2}} \\
\theta_{j}=\operatorname{arctg}\left(\frac{y_{j}(t+1)-y_{j}(t)}{x_{j}(t+1)-x_{j}(t)}\right)
\end{gathered}
$$

where $\left(x_{j}(t), y_{j}(t)\right)$ and $\left(x_{j}(t+1), y_{j}(t+1)\right)$ are the coordinates of the mean center of the $j$ th potential vegetation type in years $t$ and $t+1$, respectively; $d_{j}$ is the shift distance of the mean center of the $j$ th potential vegetation type during the period from $t$ to $t+1$; and $\theta_{j}$ is the value of the angle of the shift of the mean center in the $j$ th potential vegetation type during the period from $t$ to $t+1$. The shift directions were classified into 8 types: due east is $0^{\circ}$, due north is $90^{\circ}$, due west is $180^{\circ}$ and due south is $270^{\circ}$. The shift directions are classified into these 8 types, as seen in Table 1 , based on the range of $\theta_{j}$ values. 
Table 1. The definition of the shift direction of the mean center in the potential vegetation ecosystem.

\begin{tabular}{ccc}
\hline Sketch Map of the Shift Directions & $\theta_{j}$ Value & Shift Direction \\
\hline & $345^{\circ} \sim 15^{\circ}$ & East \\
$15^{\circ} \sim 75^{\circ}$ & Northeast \\
& $75^{\circ} \sim 105^{\circ}$ & North \\
& $105^{\circ} \sim 165^{\circ}$ & Northwest \\
& $165^{\circ} \sim 195^{\circ}$ & West \\
& $195^{\circ} \sim 255^{\circ}$ & Southwest \\
& $255^{\circ} \sim 285^{\circ}$ & South \\
& $285^{\circ} \sim 345^{\circ}$ & Southeast \\
\hline
\end{tabular}

\section{Results}

\subsection{Distribution of the Mean Centers of Potential Vegetation Ecosystems}

The potential vegetation ecosystems simulation results showed that there were 32 vegetation ecosystem types in Eurasia from 1981 to 2010, as seen in Figure 2. Cold temperate wet forest, cool temperate moist forest and desert were the main vegetation ecosystem types, which covered $14.49 \%$, $11.61 \%$ and $10.61 \%$ of the total area of Eurasia, respectively. The cold temperate wet forest was mainly distributed in the Central Siberian Plateau, the central part of the West Siberian Plain, and the northern part of the Eastern European Plain; the mean center of all patches of this ecosystem was located in the southeastern part of the West Siberian Plain. The cool temperate moist forest was mainly distributed in the Loess Plateau and Northeast China Plain, the Korean Peninsula, and the southern and western parts of the European Plain; the mean center of all patches of this ecosystem was located in the Turan Plain of Russia. The desert was mainly distributed in the western part of the Mongolian Plateau, the Turan Plain, the Arabian Peninsula and the eastern part of the Iranian Plateau, which include the Gobi Desert, Taklimakan Desert, Karakum Desert, Kyzylkum Desert, Arabian Desert and Thar Desert; the mean center of all patches of this ecosystem was located in the eastern part of the Iranian Plateau. The results indicate that the simulations of the spatial distributions of the potential vegetation types and their mean centers could be effectively used to understand the response of the potential vegetation types to climate change in Eurasia.

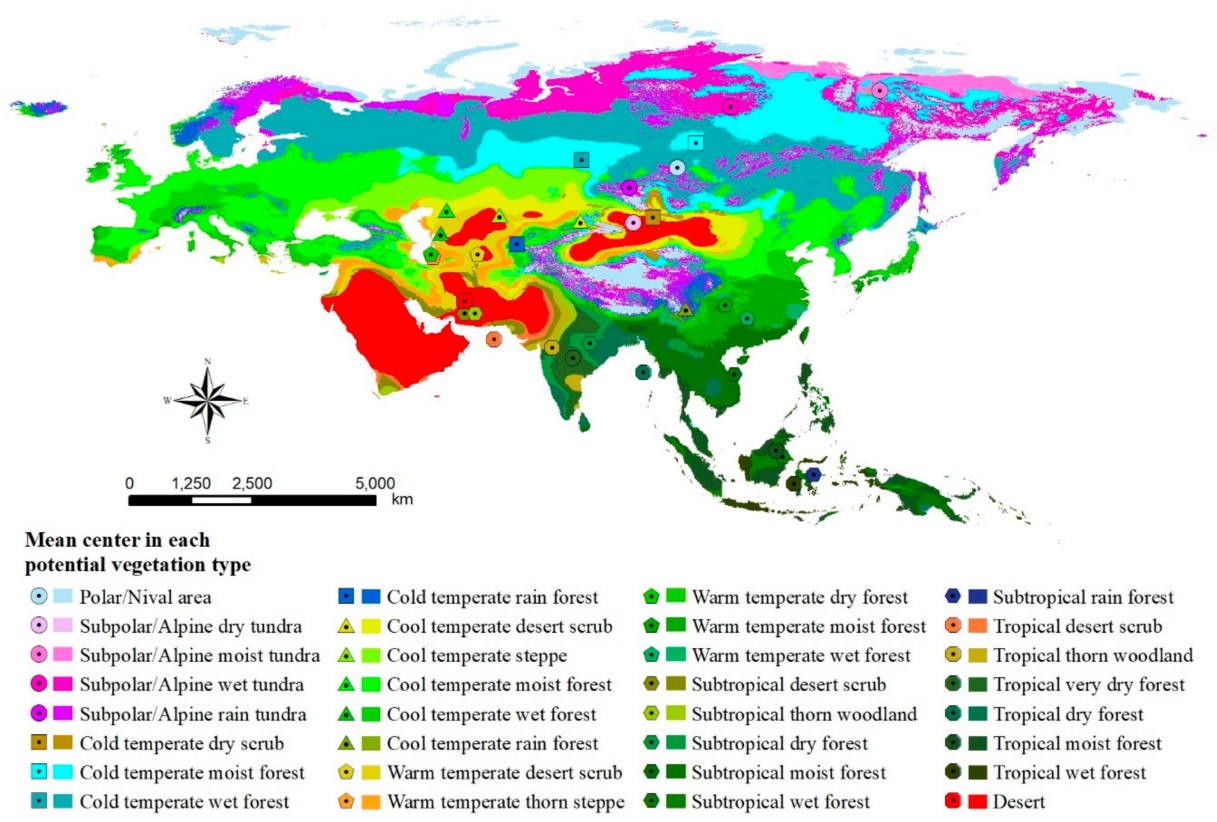

Figure 2. Distribution of the mean centers of potential vegetation ecosystems in Eurasia in the T0 period. 


\subsection{Shift Trends of the Mean Center of Potential Vegetation Types}

The simulation results of the mean centers of potential vegetation types show that the mean centers of the subtropical dry forest, warm temperate moist forest, tropical thorn woodland and subtropical wet forest ecosystems would exhibit the largest shift distances of more than $150 \mathrm{~km}$ per decade during the period from T0 to T3 under the RCP2.6 scenario, as seen in Table 2, Figure 3. The mean centers of the cool temperate rain forest, tropical very dry forest, tropical thorn woodland, desert. and tropical moist forest ecosystems would shift less than $25 \mathrm{~km}$ per decade during these periods under the same scenario. The subtropical thorn woodland, cold temperate moist forest, subpolar/alpine dry tundra, and tropical very dry forest ecosystems would shift $1548 \mathrm{~km}$ northwest, $1199 \mathrm{~km}$ northeast, $286 \mathrm{~km}$ southwest, and $121 \mathrm{~km}$ northwest, respectively, during the period from T0 to T3.

Table 2. Shift distances $(\mathrm{km})$ and directions of the mean center of each potential vegetation type under the RCP2.6 scenario in Eurasia.

\begin{tabular}{|c|c|c|c|c|c|c|}
\hline \multirow{2}{*}{ Type } & \multicolumn{2}{|c|}{ T0-T1 } & \multicolumn{2}{|c|}{ T1-T2 } & \multicolumn{2}{|c|}{ T2-T3 } \\
\hline & $\begin{array}{c}\text { Shift } \\
\text { Distance }\end{array}$ & $\begin{array}{c}\text { Shift } \\
\text { Direction }\end{array}$ & $\begin{array}{c}\text { Shift } \\
\text { Distance }\end{array}$ & $\begin{array}{c}\text { Shift } \\
\text { Direction }\end{array}$ & $\begin{array}{c}\text { Shift } \\
\text { Distance }\end{array}$ & $\begin{array}{c}\text { Shift } \\
\text { Direction }\end{array}$ \\
\hline Subpolar/Alpine dry tundra & 41 & Southwest & 185 & Southwest & 60 & Southwest \\
\hline Subpolar/Alpine moist tundra & 80 & South & 218 & Southwest & 454 & Southwest \\
\hline Subpolar/Alpine wet tundra & 425 & East & 95 & Northwest & 156 & West \\
\hline Cold temperate moist forest & 511 & Northeast & 272 & Northeast & 416 & Northeast \\
\hline Cold temperate wet forest & 265 & Northeast & 234 & East & 161 & Northeast \\
\hline Cold temperate rain forest & 212 & East & 204 & East & 99 & Southeast \\
\hline Cool temperate desert scrub & 114 & Northeast & 91 & East & 77 & Northeast \\
\hline Cool temperate steppe & 155 & Northeast & 176 & Northeast & 162 & Northeast \\
\hline Warm temperate thorn steppe & 276 & Northeast & 175 & Northeast & 154 & Northeast \\
\hline Warm temperate dry forest & 309 & Northwest & 198 & Northwest & 250 & East \\
\hline Warm temperate moist forest & 451 & Northwest & 647 & West & 934 & West \\
\hline Warm temperate wet forest & 177 & Northwest & 107 & Northwest & 185 & West \\
\hline Subtropical desert scrub & 282 & Northwest & 218 & North & 166 & North \\
\hline Subtropical thorn woodland & 843 & Northwest & 496 & Northwest & 209 & Northwest \\
\hline Subtropical dry forest & 755 & Northwest & 639 & Northwest & 847 & West \\
\hline Subtropical moist forest & 597 & Northwest & 271 & North & 165 & Northeast \\
\hline Subtropical wet forest & 524 & Northeast & 475 & Northwest & 548 & Northwest \\
\hline Subtropical rain forest & 116 & Northeast & 127 & East & 0 & East \\
\hline Tropical desert scrub & 63 & North & 55 & North & 109 & West \\
\hline
\end{tabular}

Under the RCP4.5 scenario seen in Table 3, Figure 4, the results show that the shift distances of the mean centers of the subpolar/alpine moist tundra, subtropical dry forest, warm temperate moist forest, cool temperate wet forest, subtropical thorn woodland, cool temperate moist forest, subtropical wet forest, and cold temperate moist forest would be larger than those in other potential vegetation types and would shift more than $200 \mathrm{~km}$ per decade on average, while those of the cool temperate rain forest, tropical very dry forest, desert, and tropical thorn woodland would shift less than $29 \mathrm{~km}$ per decade during the period from T0 to T3. The cool temperate wet forest, subtropical thorn woodland, cold temperate moist forest, and tropical wet forest ecosystems would continue to shift $1982 \mathrm{~km}$ east, $1741 \mathrm{~km}$ northwest, $1278 \mathrm{~km}$ northeast, and $264 \mathrm{~km}$ east, respectively, during the period from T0 to T3. 


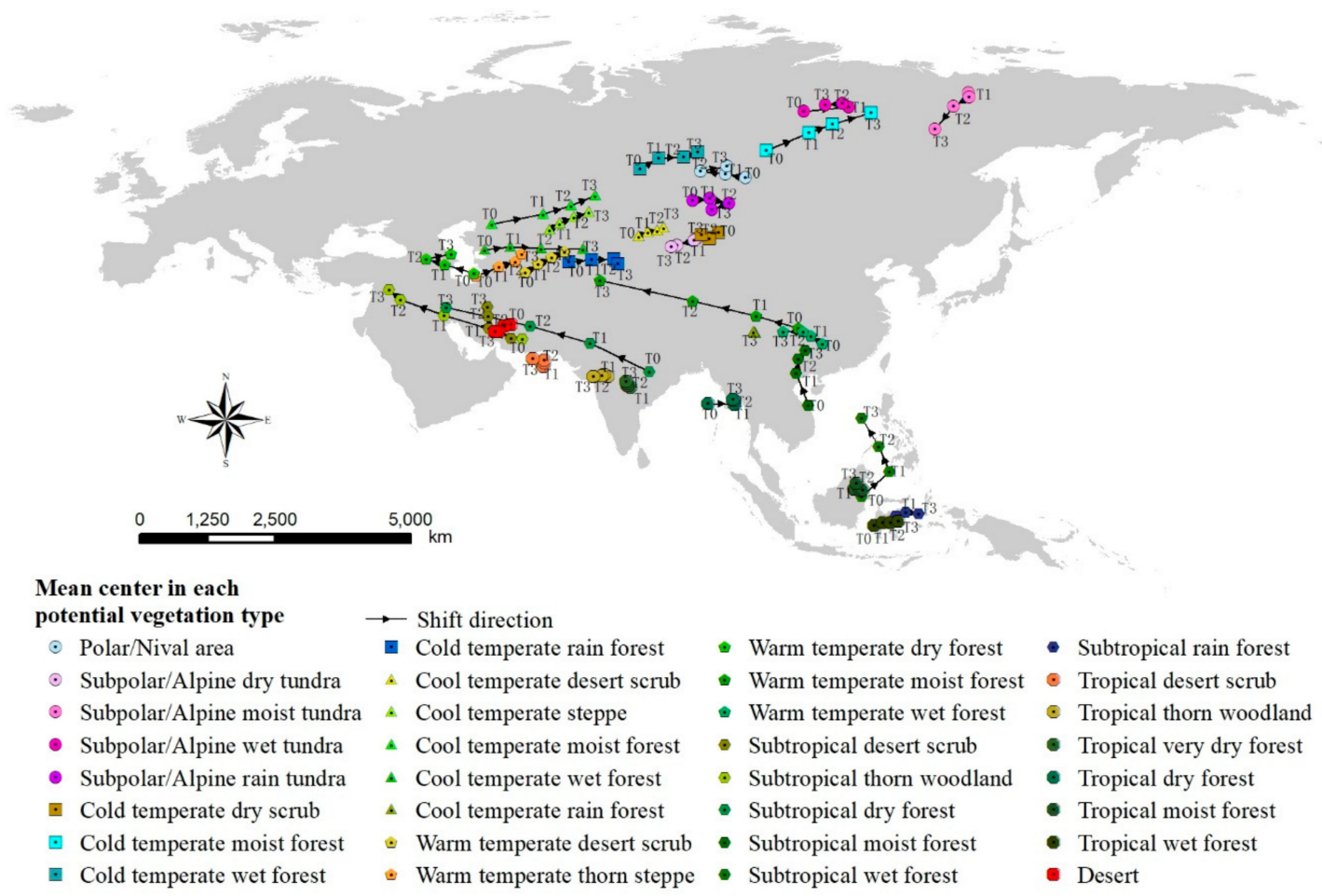

Figure 3. Shift trends of the mean centers of each potential vegetation type under the RCP2.6 scenario in Eurasia.

Table 3. Shift distances $(\mathrm{km})$ and directions of the mean centers of each potential vegetation type under the RCP4.5 scenario in Eurasia.

\begin{tabular}{|c|c|c|c|c|c|c|}
\hline \multirow{2}{*}{ Type } & \multicolumn{2}{|c|}{ T0-T1 } & \multicolumn{2}{|c|}{ T1-T2 } & \multicolumn{2}{|c|}{ T2-T3 } \\
\hline & $\begin{array}{c}\text { Shift } \\
\text { Distance }\end{array}$ & $\begin{array}{c}\text { Shift } \\
\text { Direction }\end{array}$ & $\begin{array}{c}\text { Shift } \\
\text { Distance }\end{array}$ & $\begin{array}{c}\text { Shift } \\
\text { Direction }\end{array}$ & $\begin{array}{c}\text { Shift } \\
\text { Distance }\end{array}$ & $\begin{array}{c}\text { Shift } \\
\text { Direction }\end{array}$ \\
\hline Polar/Nival area & 178 & West & 283 & West & 720 & Northeast \\
\hline Subpolar/Alpine dry tundra & 142 & Southwest & 92 & Southwest & 74 & West \\
\hline Subpolar/Alpine moist tundra & 94 & Southeast & 270 & Southwest & 2031 & Southwest \\
\hline Subpolar/Alpine wet tundra & 388 & East & 53 & Southeast & 394 & West \\
\hline Subpolar/Alpine rain tundra & 255 & East & 166 & Southeast & 119 & Southwest \\
\hline Cold temperate dry scrub & 147 & Southwest & 30 & West & 167 & West \\
\hline Cold temperate moist forest & 549 & Northeast & 358 & Northeast & 370 & Northeast \\
\hline Cold temperate wet forest & 217 & Northeast & 340 & East & 322 & East \\
\hline Cold temperate rain forest & 190 & East & 301 & East & 209 & Northeast \\
\hline Cool temperate desert scrub & 191 & East & 101 & Northeast & 172 & East \\
\hline Cool temperate steppe & 186 & Northeast & 231 & Northeast & 567 & East \\
\hline Cool temperate moist forest & 328 & Northeast & 469 & East & 574 & Northeast \\
\hline Cool temperate wet forest & 215 & East & 717 & East & 1050 & East \\
\hline Cool temperate rain forest & 17 & Southwest & 4 & North & 70 & North \\
\hline Warm temperate desert scrub & 285 & Northeast & 211 & Northeast & 330 & East \\
\hline Warm temperate thorn steppe & 295 & Northeast & 235 & Northeast & 229 & Northeast \\
\hline Warm temperate dry forest & 141 & Northwest & 375 & West & 363 & Northwest \\
\hline Warm temperate moist forest & 307 & Northwest & 912 & West & 789 & Northwest \\
\hline Warm temperate wet forest & 47 & Northwest & 244 & Northwest & 147 & North \\
\hline Subtropical desert scrub & 243 & Northwest & 327 & North & 270 & Northwest \\
\hline Subtropical thorn woodland & 595 & Northwest & 654 & Northwest & 492 & Northwest \\
\hline Subtropical dry forest & 423 & Northwest & 840 & Northwest & 921 & West \\
\hline Subtropical moist forest & 488 & Northwest & 336 & Northeast & 274 & Northeast \\
\hline Subtropical wet forest & 235 & Northeast & 765 & North & 368 & Northwest \\
\hline
\end{tabular}


Table 3. Cont.

\begin{tabular}{|c|c|c|c|c|c|c|}
\hline \multirow{2}{*}{ Type } & \multicolumn{2}{|c|}{ T0-T1 } & \multicolumn{2}{|c|}{ T1-T2 } & \multicolumn{2}{|c|}{ T2-T3 } \\
\hline & $\begin{array}{c}\text { Shift } \\
\text { Distance }\end{array}$ & $\begin{array}{c}\text { Shift } \\
\text { Direction }\end{array}$ & $\begin{array}{c}\text { Shift } \\
\text { Distance }\end{array}$ & $\begin{array}{c}\text { Shift } \\
\text { Direction }\end{array}$ & $\begin{array}{c}\text { Shift } \\
\text { Distance }\end{array}$ & $\begin{array}{c}\text { Shift } \\
\text { Direction }\end{array}$ \\
\hline Tropical desert scrub & 105 & Northwest & 63 & West & 102 & Northwest \\
\hline Tropical thorn woodland & 85 & Northwest & 38 & Southwest & 129 & West \\
\hline Tropical very dry forest & 40 & Northwest & 57 & North & 52 & Northwest \\
\hline Tropical moist forest & 95 & Southeast & 83 & Northwest & 238 & Northwest \\
\hline Tropical wet forest & 167 & East & 34 & East & 63 & East \\
\hline Desert & 114 & Southwest & 56 & West & 61 & Northwest \\
\hline
\end{tabular}

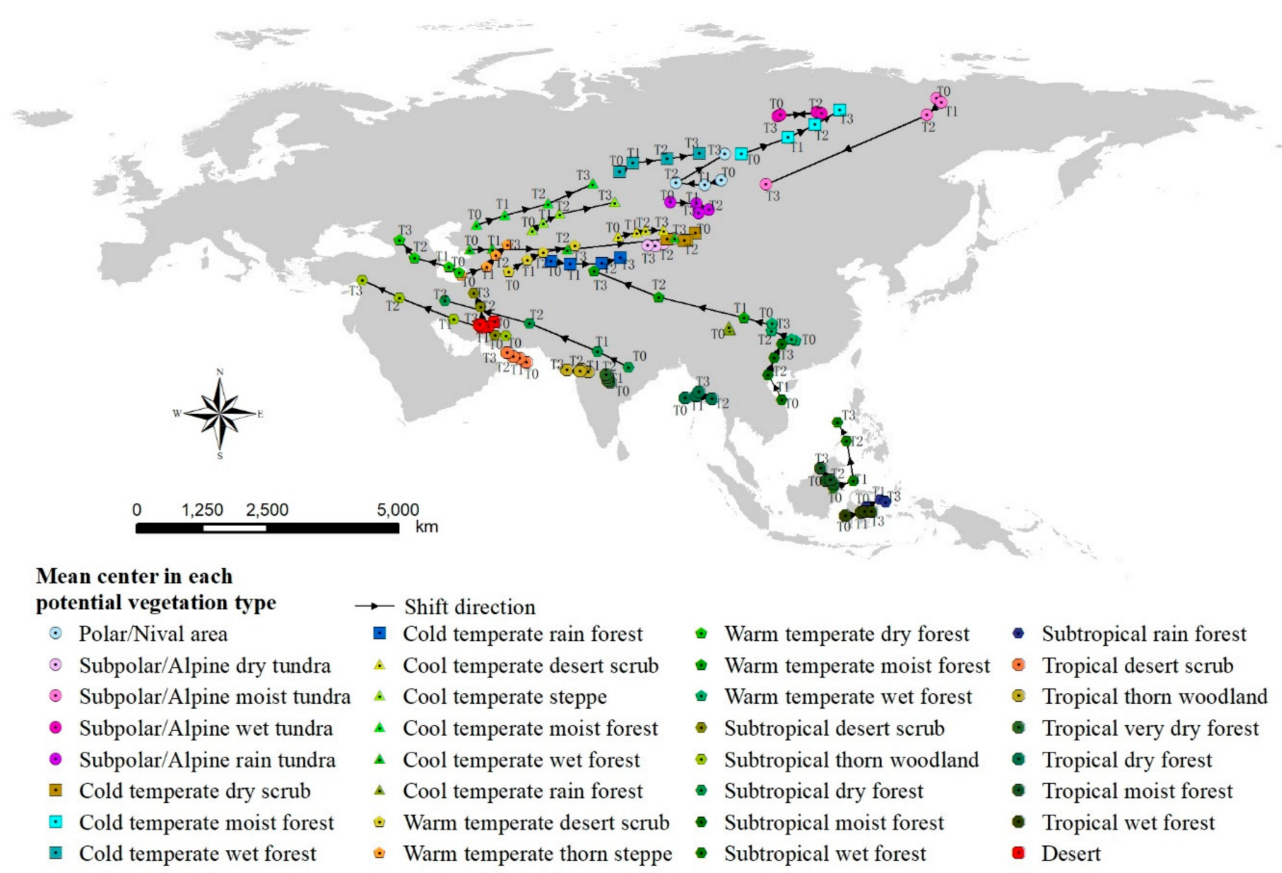

Figure 4. Shift trends of the mean centers of each potential vegetation type under the RCP4.5 scenario in Eurasia.

Under the RCP8.5 scenario seen in Table 4, Figure 5, the results showed that the shift distances of the mean centers of the subpolar/alpine moist tundra, subtropical dry forest, warm temperate moist forest, cool temperate wet forest, subtropical wet forest, subtropical thorn woodland, cool temperate moist forest, cold temperate moist forest, polar/nival area, and subtropical moist forest would be larger than those of other potential vegetation types with a shift distance of more than $200 \mathrm{~km}$ per decade on average, while those of the cool temperate rain forest, tropical very dry forest, desert, and cold temperate dry scrub would shift less than $45 \mathrm{~km}$ per decade during the period from T0 to T3. The subpolar/alpine moist tundra, cool temperate wet forest, cool temperate moist forest, cold temperate moist forest, and cool temperate desert scrub would continue to shift $3864 \mathrm{~km}$ southwest, $2188 \mathrm{~km}$ east, $1726 \mathrm{~km}$ northeast, $1506 \mathrm{~km}$ northeast, and $649 \mathrm{~km}$ east, respectively, during the period from T0 to T3. 
Table 4. Shift distances $(\mathrm{km})$ and directions of the mean centers of each potential vegetation type under the RCP8.5 scenario in Eurasia.

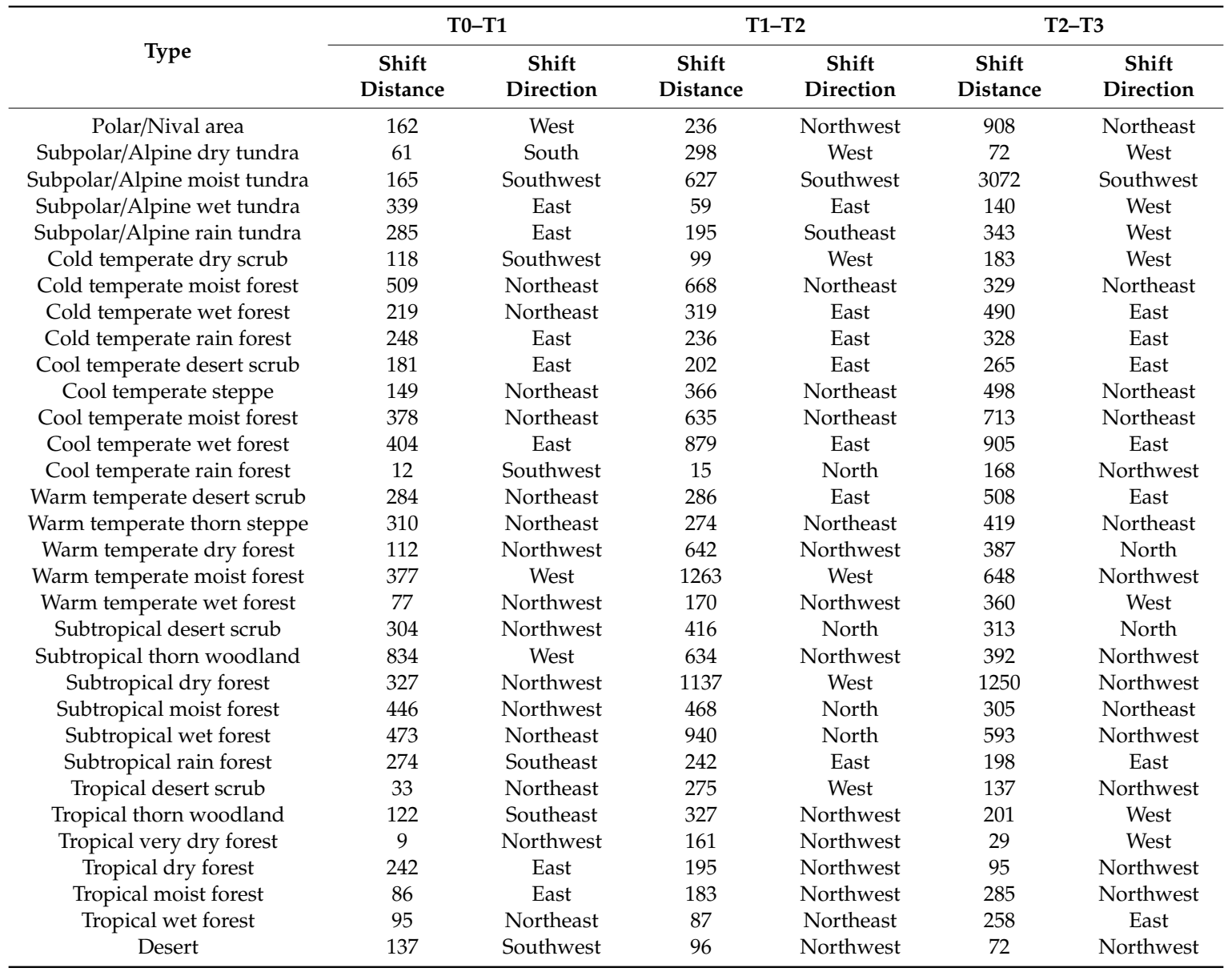

In general, during the periods from T0 to T3, the mean centers of the subtropical dry forest and warm temperate moist forest ecosystems would show the largest shift distances; the subtropical dry forest would shift $249 \mathrm{~km}, 243 \mathrm{~km}$, and $302 \mathrm{~km}$ per decade on average towards the northwest under the RCP2.6, RCP4.5, and RCP8.5 scenarios, respectively, and the warm temperate moist forest would generally shift $226 \mathrm{~km}, 223 \mathrm{~km}$, and $254 \mathrm{~km}$ per decade towards the northwest under the three scenarios, respectively. These results indicate that the distributions of subtropical dry forest and warm temperate moist forest would be increased in southwest Europe, and decreased in the Indian Peninsula and China. The mean centers of both cool temperate rain forest and tropical very dry forest would generally shift less than $23 \mathrm{~km}$ north, which means that their distributions will move north under future climate change. 


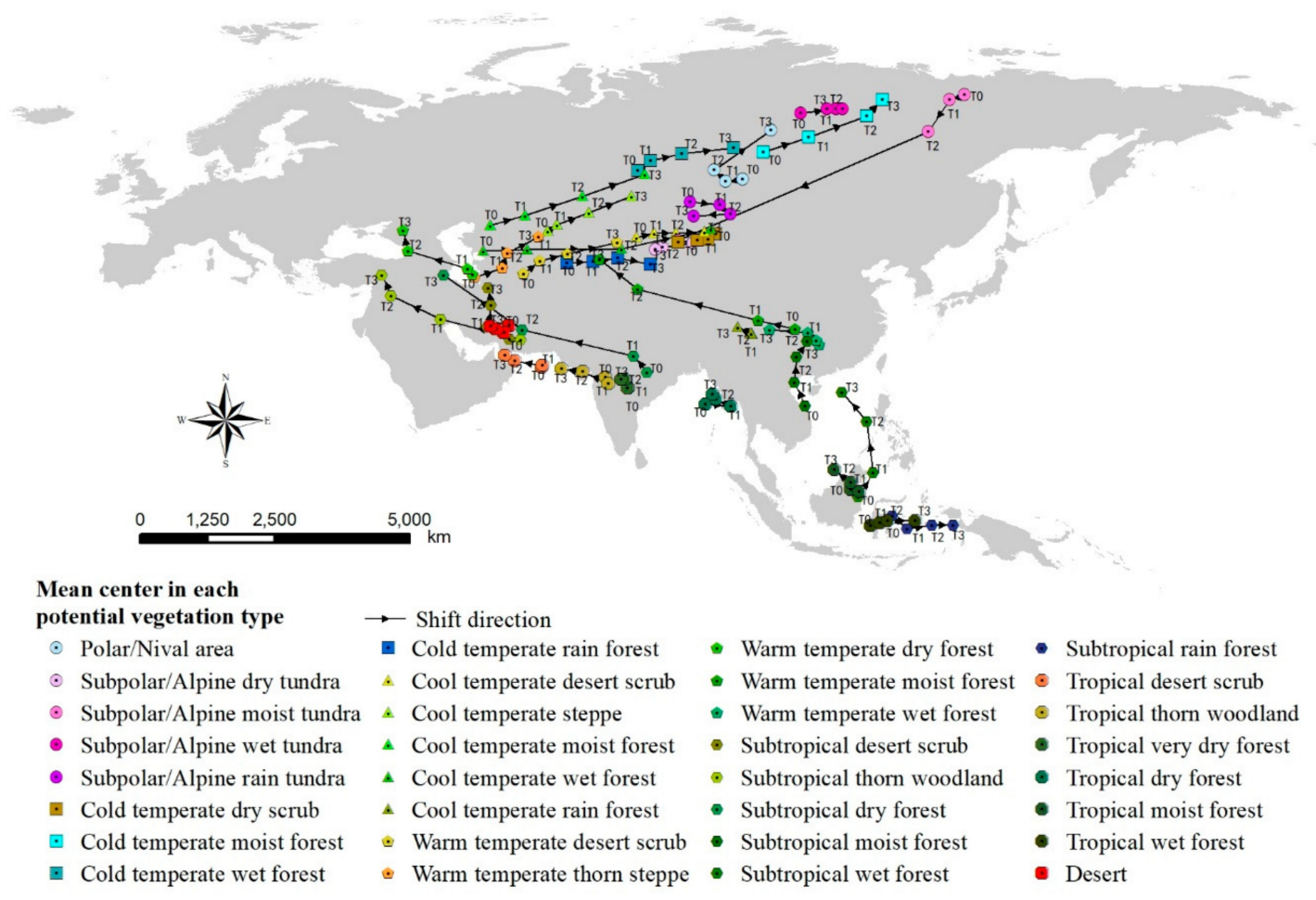

Figure 5. Shift trends of the mean centers of each potential vegetation type under the RCP8.5 scenario in Eurasia.

\section{Discussion}

The HASM method [11,41,42] was utilized to obtain high-resolution and high-accuracy climate data by interpolating the station observational climate data and downscaling the climate scenario data. The HLZ ecosystem model [9], as a bioclimatic classification scheme [48], has been widely used to simulate the distributions of terrestrial ecosystems [35,36,49], predict land cover change [47], and support land use planning [20-25]. In this paper, the HLZ ecosystem model was improved to simulate the distribution of the potential vegetation type. The shift model of mean center $[11,37,47]$ was improved to quantitatively compute the shift distance and direction of the mean center of each potential vegetation type in Eurasia during the period from 1981 to 2100. The mean center of a given potential vegetation type represented the distribution center weighed by the area of that vegetation ecosystem type. Therefore, the shift distance and direction of the mean center of a vegetation ecosystem type could be used to explain the response of the potential vegetation distributions to climate change [37]. Moreover, related studies show that the existing biogeographical model of potential vegetation ecosystems could be used to predict the impacts of future climate change on different vegetation types [50]. A carbon storage/sequestration model of potential vegetation ecosystems could be used to estimate the changes in carbon storage and sequestration potential in response to climate change [51], and a shift model of mean center could be used to predict the shift intensity of the mean centers of different potential vegetation types [52-54].

Under future climate change, the subtropical dry forest, warm temperate moist forest and subpolar/alpine moist tundra would be more sensitive to climate change than the other vegetation ecosystem types, which can be identified from existing reports [37,55-57]. The amount of polar/nival area will be reduced and replaced by subpolar/alpine tundra between their transition zones [30,55]. Subpolar/alpine moist tundra may be reduced by more than $90 \%$ from T0 to T3 [56], which is consistent with the fact that the shift distance of the mean center of subpolar/alpine moist tundra will generally be larger than that of other potential vegetation types. Subpolar/alpine moist tundra would be the most sensitive vegetation type because its area would have the most rapid rate of decrease [56], and its 
mean center would shift the largest distance towards the southwest, which means that subpolar/alpine moist tundra could be selected as an indicator of climatic change [11,57]. The shift distances of the mean centers of subtropical dry forest and warm temperate moist forest would be the largest of all potential vegetation types and would generally shift to the northwest from $\mathrm{T} 0$ to $\mathrm{T} 3$, which means that their distributions would increase in Europe under climate change [58].

The distributions of potential vegetation are significantly controlled by changes in climate $[59,60]$, especially changes in temperature [61]. In the three climate change scenarios, RCP8.5 is the scenario with the highest predicted change, RCP4.5 is the intermediate scenario, and RCP2.6 is the scenario with the lowest predicted change $[23,39,62]$. The results of the simulated shift trends of the mean centers of potential vegetation types were all similar in that the intensity of climate change directly affects the shift distances of the mean centers of the potential vegetation ecosystems. The mean centers of the potential vegetation types under the RCP8.5 scenario would have the largest shift distances and those under the RCP2.6 scenario would have the smallest shift distances. Under the three climate scenarios, the mean centers of the polar/nival area, subpolar/alpine moist tundra, warm temperate dry forest, subtropical moist forest, cool temperate moist forest, cool temperate wet forest, subtropical wet forest, subtropical thorn woodland, warm temperate moist forest, and subtropical dry forest would have larger shifts than those of other potential vegetation types in Eurasia, which means that these potential vegetation types would be more sensitive to climate change than the others. In contrast, the mean centers of the cool temperate rain forest, tropical very dry forest, desert, cold temperate dry scrub, subpolar/alpine dry tundra, tropical wet forest, tropical desert scrub, tropical dry forest, and tropical moist forest would shift less than those of other potential vegetation types in Eurasia, which means that these potential vegetation types would be the least vulnerable to climate change.

With increasing temperature and precipitation, the potential vegetation ecosystem types would generally show conversion from cool-dry to warm-wet and from cool to warm in Eurasia [56]; the distributions showed trends of shifting to higher latitudes and elevations [62,63], especially in the Northern Hemisphere between the latitudes of $35^{\circ}$ and $75^{\circ}$ [64]. The simulation results of the shift trends of the mean center of the potential vegetation types showed a similar response, in which the polar/nival area would decrease in the southeast part of the north polar area [56], leading to a mean center shift towards the west. The change in the desert distribution would mainly occur around the existing desert areas [56], and its mean center would generally shift less than $35 \mathrm{~km}$ per decade to the west. Moreover, the mean centers of the cold temperate moist forest and warm temperate thorn steppe would continuously shift towards the northeast, and the mean center of the cool temperate wet forest would continuously shift towards the east during the period from T0 to T3 under the three scenarios.

In summary, the simulation results of the shift in the mean center of the different potential vegetation ecosystem types could be used to explicitly analyze the responses of different shift trends in vegetation ecosystem types under different climate change scenarios in Eurasia.

\section{Conclusions}

The simulation results indicated that the distributions of potential vegetation types would shift northward under the three climate change scenarios of RCP2.6, RCP4.5, and RCP8.5 during the periods from 1981 to 2100 . Based on the results of the shift trends of the mean center of the potential vegetation types, we recommend that the subpolar/alpine moist tundra, subtropical dry forest, and warm temperate moist forest be selected as indicators of the response of vegetation to climate change because their shift distances are generally larger than other vegetation types. Moreover, understanding the shift trends of the mean center of potential vegetation would be beneficial for researching the future carbon balance of vegetation ecosystems, which could be approved by the data support for planning the sustainable development of the countries in Belt and Road Initiative (BRI) regions.

Author Contributions: Conceptualization, Z.F.; methodology, Z.F.; software, Z.F. and B.F.; validation, Z.F.; formal analysis, Z.F.; investigation, Z.F. and B.F.; resources, Z.F.; data curation, Z.F. and B.F.; writing一original draft 
preparation, Z.F. and B.F.; writing—review and editing, Z.F.; visualization, Z.F. and B.F.; supervision, Z.F.; project administration, Z.F.; and funding acquisition, Z.F.

Funding: This research was funded by the National Key R\&D Program of China (2017YFA0603702 and 2018YFC0507202), the Strategic Priority Research Program (A) of the Chinese Academy of Sciences (XDA20030203), the National Natural Science Foundation (41971358), and the Innovation Project of State Key Laboratory of Resources and Environmental Information System (O88RA600YA).

Conflicts of Interest: The authors declare no conflict of interest.

\section{References}

1. Ye, D.Z.; Fu, C.B.; Dong, W.J. Progresses and future trends of global change sciences. Adv. Earth Sci. 2002, 17, 467-469. (In Chinese)

2. Willis, K.J.; Jeffers, E.S.; Tovar, C. What makes a terrestrial ecosystem resilient? Science 2018, 359, 988-989. [CrossRef] [PubMed]

3. Zhou, G.S.; Zhang, X.S. Feedback of vegetation on climate. Acta Bot. Sin. 1996, 38, 1-7. (In Chinese)

4. Scholze, M.; Knorr, W.; Arnell, N.W.; Prentice, I.C. A climate-change risk analysis for world ecosystems. Proc. Natl. Acad. Sci. USA 2006, 103, 13116-13120. [CrossRef] [PubMed]

5. Biermann, F. 'Earth system governance' as a crosscutting theme of global change research. Glob. Environ. Chang. 2007, 17, 326-337. [CrossRef]

6. Nemani, R.R.; Keeling, C.D.; Hashimoto, H.; Jolly, W.M.; Piper, S.C.; Tucker, C.J.; Myneni, R.B.; Running, S.W. Climate-driven increases in global terrestrial net primary production from 1982 to 1999. Science 2003, 300, 1560-1563. [CrossRef] [PubMed]

7. Schouw, J.F. Grundzuege einer Allgemeinen Pflanzengeographie; Reimer: Berlin, Germany, 1823.

8. Woodward, F.I. Climate and Plant Distribution; Cambridge University Press: Cambridge, UK, 1987.

9. Holdridge, L.R. Life Zone Ecology; Tropical Science Center: San José, Costa Rica, 1967.

10. Yue, T.X.; Liu, J.Y.; Jørgensen, S.E.; Gao, Z.Q.; Zhang, S.H.; Deng, X.Z. Changes of Holdridge life zone diversity in all of China over a half century. Ecol. Model. 2001, 144, 153-162. [CrossRef]

11. Yue, T.X.; Fan, Z.M.; Chen, C.F.; Sun, X.F.; Li, B.L. Surface modelling of global terrestrial ecosystems under three climate change scenarios. Ecol. Model. 2011, 222, 2342-2361. [CrossRef]

12. Leemans, R.; Eickhout, B. Another reason for concern: Regional and global impacts on ecosystems for different levels of climate change. Glob. Environ. Chang. 2004, 14, 219-228. [CrossRef]

13. Li, N.; Xie, G.D.; Zhang, C.S.; Xiao, Y.; Zhang, B.A.; Chen, W.H.; Sun, Y.Z.; Wang, S. Biomass Resources Distribution in the Terrestrial Ecosystem of China. Sustainability 2015, 7, 8548-8564. [CrossRef]

14. Zhu, Z.C.; Piao, S.L.; Myneni, R.B.; Huang, M.T.; Zeng, Z.Z.; Canadell, J.G.; Ciais, P.; Sitch, S.; Friedlingstein, P.; Arneth, A.; et al. Greening of the Earth and its drivers. Nat. Clim. Chang. 2016, 6, 791-795. [CrossRef]

15. Stan, K.; Sanchez-Azofeifa, A. Tropical Dry Forest Diversity, Climatic Response, and Resilience in a Changing Climate. Forests 2019, 10, 443. [CrossRef]

16. Yue, T.X.; Fan, Z.M. A review of responses of typical terrestrial ecosystems to climate change. Chin. Sci. Bull. 2014, 59, 217-231. (In Chinese)

17. Box, E.O. Predicting Physiognomic Vegetation Types with Climate Variables. Vegetatio 1981, 45, 127-139. [CrossRef]

18. Neilson, R.P.; King, G.A.; Koerper, G. Toward a Rule-Based Biome Model. Landsc. Ecol. 1992, 7, $27-43$. [CrossRef]

19. Foley, J.A.; Prentice, I.C.; Ramankutty, N.; Levis, S.; Pollard, D.; Sitch, S.; Haxeltine, A. An integrated biosphere model of land surface processes, terrestrial carbon balance, and vegetation dynamics. Global Biogeochem. Cycles 1996, 10, 603-628. [CrossRef]

20. Post, W.M.; Emanuel, W.R.; Zinke, P.J.; Stangenberger, A.G. Soil carbon pools and world life zones. Nature 1982, 298, 156-159. [CrossRef]

21. Lugo, A.E.; Brown, S.L.; Dodson, R.; Smith, T.S.; Shugart, H.H. The Holdridge life zones of the conterminous United States in relation to ecosystem mapping. J. Biogeogr. 1999, 26, 1025-1038. [CrossRef]

22. Fan, Z.M.; Li, J.; Yue, T.X. Land-cover changes of biome transition zones in Loess Plateau of China. Ecol. Model. 2013, 252, 129-140. [CrossRef] 
23. Fan, Z.M.; Li, J.; Yue, T.X.; Zhou, X.; Lan, A.J. Scenarios of land cover in Karst area of Southwestern China. Environ. Earth Sci. 2015, 74, 6407-6420. [CrossRef]

24. Szelepcsényi, Z.; Breuer, H.; Kis, A.; Pongrácz, R.; Sümegi, P. Assessment of projected climate change in the Carpathian Region using the Holdridge life zone system. Theor. Appl. Climatol. 2018, 131, 593-610. [CrossRef]

25. Herrick, J.E.; Bestelmeyer, B.T.; Archer, S.; Tugel, A.J.; Brown, J.R. An integrated framework for science-based arid land management. J. Arid Environ. 2006, 65, 319-335. [CrossRef]

26. Weismiller, R.A.; Kristof, S.J.; Scholz, D.K.; Anuta, P.E.; Momin, S.A. Change Detection in Coastal Zone Environments. Photogramm. Eng. Remote Sens. 1977, 43, 1533-1539.

27. Belotelov, N.V.; Bogatyrev, B.G.; Kirilenko, A.P.; Venevsky, S.V. Modelling of time-dependent biome shifts under global climate changes. Ecol. Model. 1996, 87, 29-40. [CrossRef]

28. Walther, G.R.; Post, E.; Convey, P.; Menzel, A.; Parmesan, C.; Beebee, T.J.C.; Fromentin, J.M.; Hoegh-Guldberg, O.; Bairlein, F. Ecological responses to recent climate change. Nature 2002, 416, 389-395. [CrossRef] [PubMed]

29. Walther, G.R. Community and ecosystem responses to recent climate change. Philos. Trans. R. Soc. B 2010, 365, 2019-2024. [CrossRef] [PubMed]

30. Nolan, C.; Overpeck, J.T.; Allen, J.R.M.; Anderson, P.M.; Betancourt, J.L.; Binney, H.A.; Brewer, S.; Bush, M.B.; Chase, B.M.; Cheddadi, R.; et al. Past and future global transformation of terrestrial ecosystems under climate change. Science 2018, 361, 920-923. [CrossRef]

31. Thomas, C.D.; Cameron, A.; Green, R.E.; Bakkenes, M.; Beaumont, L.J.; Collingham, Y.C.; Erasmus, B.F.N.; de Siqueira, M.F.; Grainger, A.; Hannah, L.; et al. Extinction risk from climate change. Nature 2004, 427, 145-148. [CrossRef]

32. Dury, M.; Mertens, L.; Fayolle, A.; Verbeeck, H.; Hambuckers, A.; Francois, L. Refining Species Traits in a Dynamic Vegetation Model to Project the Impacts of Climate Change on Tropical Trees in Central Africa. Forests 2018, 9, 722. [CrossRef]

33. Yu, M.; Wang, G.L.; Parr, D.; Ahmed, K.F. Future changes of the terrestrial ecosystem based on a dynamic vegetation model driven with RCP8.5 climate projections from 19 GCMs. Clim. Chang. 2014, 127, 257-271. [CrossRef]

34. Han, Q.F.; Luo, G.P.; Li, C.F.; Li, S.B. Response of Carbon Dynamics to Climate Change Varied among Different Vegetation Types in Central Asia. Sustainability 2018, 10, 3288. [CrossRef]

35. Yue, T.X.; Fan, Z.M.; Liu, J.Y. Changes of major terrestrial ecosystems in China since 1960. Glob. Planet. Chang. 2005, 48, 287-302. [CrossRef]

36. He, Y.B.; Chen, Y.Q.; Tang, H.J.; Yao, Y.M.; Yang, P.; Chen, Z.X. Exploring spatial change and gravity center movement for ecosystem services value using a spatially explicit ecosystem services value index and gravity model. Environ. Monit. Assess. 2011, 175, 563-571. [CrossRef] [PubMed]

37. Yue, T.X.; Fan, Z.M.; Liu, J.Y.; Wei, B.X. Scenarios of major terrestrial ecosystems in China. Ecol. Model. 2006, 199, 363-376. [CrossRef]

38. Zhang, G.G.; Kang, Y.M.; Han, G.D.; Sakurai, K. Effect of climate change over the past half century on the distribution, extent and NPP of ecosystems of Inner Mongolia. Glob. Chang. Biol. 2011, 17, 377-389. [CrossRef]

39. Van Vuuren, D.P.; Edmonds, J.; Kainuma, M.; Riahi, K.; Thomson, A.; Hibbard, K.; Hurtt, G.C.; Kram, T.; Krey, V.; Lamarque, J.F.; et al. The representative concentration pathways: An overview. Clim. Chang. 2011, 109, 5-31. [CrossRef]

40. Yue, T.X. Surface Modeling: High Accuracy and High Speed Methods; CRC Press: New York, NY, USA, 2011.

41. Fan, Z.M.; Yue, T.X.; Chen, C.F. Downscaling of global mean annual temperature under different scenarios. Prog. Geogr. 2012, 31, 267-274. (In Chinese)

42. Yue, T.X.; Zhao, N.; Fan, Z.M.; Li, J.; Chen, C.F.; Lu, Y.M.; Wang, C.L.; Xu, B.; Wilson, J. CMIP5 downscaling and its uncertainty in China. Glob. Planet. Chang. 2016, 146, 30-37. [CrossRef]

43. Shaw, G.; Wheeler, D. Statistical Techniques in Geographical Analysis; Wiley: Chichester West Sussex, UK; New York, NY, USA, 1985; p. 364.

44. Hart, J.F. Central Tendency in Areal Distributions. Econo. Geogr. 1954, 30, 48-59. [CrossRef]

45. Warntz, W.; Neft, D. Contributions to a statistical methodology for areal distributions. J. Reg. Sci. 1960, 2, 47-66. [CrossRef] 
46. Ebdon, D. Statistics in Geography: A Practical Approach; B. Blackwell: Oxford, UK, 1977; p. 195.

47. Yue, T.X.; Fan, Z.M.; Liu, J.Y. Scenarios of Land cover in China. Glob. Planet. Chang. 2007, 55, 317-342. [CrossRef]

48. Solomon, A.M.; Shugart, H. Vegetation Dynamics \& Global Change; Springer Science \& Business Media: Charlottesville, VA, USA, 1993.

49. Chen, X.W.; Zhang, X.S.; Li, B.L. The possible response of life zones in China under global climate change. Glob. Planet. Chang. 2003, 38, 327-337. [CrossRef]

50. Hickler, T.; Vohland, K.; Feehan, J.; Miller, P.A.; Smith, B.; Costa, L.; Giesecke, T.; Fronzek, S.; Carter, T.R.; Cramer, W.; et al. Projecting the future distribution of European potential natural vegetation zones with a generalized, tree species-based dynamic vegetation model. Glob. Ecol. Biogeogr. 2012, 21, 50-63. [CrossRef]

51. Hui, D.; Deng, Q.; Tian, H.; Luo, Y. Climate Change and Carbon Sequestration in Forest Ecosystems. In Handbook of Climate Change Mitigation and Adaptation; Springer: Cham, Germany, 2017; pp. 555-594.

52. Mayle, F.E.; Langstroth, R.P.; Fisher, R.A.; Mair, P. Long term savannah dynamics in the Bolivian Amazon: Implications for conservation. Philos. Trans. R. Soc. B 2007, 367, 291-307. [CrossRef] [PubMed]

53. Xu, H.J.; Wang, X.P.; Yang, T.B. Trend shifts in satellite-derived vegetation growth in Central Eurasia, 1982-2013. Sci. Total Environ. 2017, 579, 1658-1674. [CrossRef] [PubMed]

54. Feng, S.; Hu, Q.; Huang, W.; Ho, C.H.; Li, R.P.; Tang, Z.H. Projected climate regime shift under future global warming from multi-model, multi-scenario CMIP5 simulations. Glob. Planet. Chang. 2014, 112, 41-52. [CrossRef]

55. Faour, G.; Mhawej, M.; Nasrallah, A. Global trends analysis of the main vegetation types throughout the past four decades. Appl. Geogr. 2018, 97, 184-195. [CrossRef]

56. Fan, Z.M.; Fan, B.; Yue, T.X. Terrestrial ecosystem scenarios and their response to climate change in Eurasia. Sci. China Earth Sci. 2019, 62, 1-12. [CrossRef]

57. Dyderski, M.K.; Paz, S.; Frelich, L.E.; Jagodzinski, A.M. How much does climate change threaten European forest tree species distributions? Glob. Chang. Biol. 2018, 24, 1150-1163. [CrossRef]

58. Machar, I.; Vlckova, V.; Bucek, A.; Vozenilek, V.; Salek, L.; Jerabkova, L. Modelling of Climate Conditions in Forest Vegetation Zones as a Support Tool for Forest Management Strategy in European Beech Dominated Forests. Forests 2017, 8, 82. [CrossRef]

59. Miao, L.J.; Liu, Q.; Fraser, R.; He, B.; Cui, X.F. Shifts in vegetation growth in response to multiple factors on the Mongolian Plateau from 1982 to 2011. Phys. Chem. Earth 2015, 87, 50-59. [CrossRef]

60. Zhou, R.W.; Li, W.J.; Zhang, Y.P.; Peng, M.C.; Wang, C.Y.; Sha, L.Q.; Liu, Y.T.; Song, Q.H.; Fei, X.H.; Jin, Y.Q.; et al. Responses of the Carbon Storage and Sequestration Potential of Forest Vegetation to Temperature Increases in Yunnan Province, SW China. Forests 2018, 9, 227. [CrossRef]

61. Weng, E.; Zhou, G. Modeling distribution changes of vegetation in China under future climate change. Environ. Model. Assess. 2006, 11, 45-58. [CrossRef]

62. Yue, T.X.; Zhao, N.; Fan, Z.M.; Li, J.; Chen, C.F.; Lu, Y.M.; Wang, C.L.; Gao, J.; Xu, B.; Jiao, Y.M.; et al. Methods for simulating climate scenarios with improved spatiotemporal specificity and less uncertainty. Glob. Planet. Chang. 2019, 181, 102973. [CrossRef]

63. Watson, R.T.; Zinyowera, M.C.; Moss, R.H. Climate Change 1995 Impacts, Adaptations and Mitigation of Climate Change: Scientific-Technical Analysis; Cambridge University Press: Cambridge, UK, 1996.

64. Beck, H.E.; McVicar, T.R.; van Dijk, A.I.J.M.; Schellekens, J.; de Jeu, R.A.M.; Bruijnzeel, L.A. Global evaluation of four AVHRR-NDVI data sets: Intercomparison and assessment against Landsat imagery. Remote Sens. Environ. 2011, 115, 2547-2563. [CrossRef]

(C) 2019 by the authors. Licensee MDPI, Basel, Switzerland. This article is an open access article distributed under the terms and conditions of the Creative Commons Attribution (CC BY) license (http://creativecommons.org/licenses/by/4.0/). 